\title{
Effects of Mineral Soil and Forest Floor on the Regeneration of Pedunculate Oak, Beech and Red Oak
}

\author{
Stefanie R. E. De Groote ${ }^{1, *} \mathbb{C}^{\mathbb{C}}$, Margot Vanhellemont ${ }^{1}$, Lander Baeten ${ }^{1}$, María M. Carón ${ }^{2}$, \\ An Martel ${ }^{3}$, Dries Bonte ${ }^{4}$, Luc Lens ${ }^{4}$ and Kris Verheyen ${ }^{1}$ \\ 1 Forest \& Nature Lab, Department of Forest and Water Management, Ghent University, \\ Geraardsbergsesteenweg 267, 9090 Gontrode, Belgium; Margot.Vanhellemont@UGent.be (M.V.); \\ Lander.Baeten@UGent.be (L.B.); Kris.Verheyen@UGent.be (K.V.) \\ 2 Laboratorio de Investigaciones Botánicas (LABIBO), Facultad de Ciencias Naturales, \\ Universidad Nacional de Salta-CONICET, Av. Bolivia 5150, 4400 Salta, Argentina; mechicaron@gmail.com \\ 3 Department Pathology, Bacteriology and Avian Diseases, Ghent University, Salisburylaan 133, \\ 9820 Merelbeke, Belgium; An.Martel@UGent.be \\ 4 Terrestrial Ecology Unit (TEREC), Department of Biology, Ghent University, K.L. Ledeganckstraat 35, \\ 9000 Gent, Belgium; Dries.Bonte@UGent.be (D.B.); Luc.Lens@UGent.be (L.L.) \\ * Correspondence: Stefanie.DeGroote@UGent.be; Tel.: +32-9264-9046
}

Received: 5 January 2018; Accepted: 25 January 2018; Published: 27 January 2018

\begin{abstract}
Early regeneration is a critical life stage that affects the future species composition of forests. Knowledge about regeneration success under different environmental conditions allows better understanding of forest dynamics. We studied the effects of seedbed conditions on the establishment and performance of seedlings of pedunculate oak, beech and red oak. In 50 plots of a tree-diversity oriented research platform in mature forests in northern Belgium (TREEWEB), we installed a field experiment with three treatments (potting soil, mineral soil, mineral soil + forest floor), in which we sowed seeds of each species. We monitored early establishment and survival, height, root and shoot biomass of the seedlings after two growing seasons. Mineral soil negatively affected seedling establishment and performance relative to the potting soil. The negative soil effects did not vary with measured abiotic soil properties. In general, the forest floor did not deteriorate or mitigate the soil effects, and only for root biomass did the forest floor partly compensate the negative soil effects. Forest floor effects did not vary with the measured forest floor properties. In the studied forests, creating bare soil was not enough to promote regeneration; improving soil properties might be important for the success of natural regeneration.
\end{abstract}

Keywords: seedling establishment; seedling performance; field experiment; TREEWEB; soil properties; forest floor properties

\section{Introduction}

The increased interest in close-to-nature forestry to restore and enhance forest functions [1] and the economic pressure to reduce forest regeneration costs favour the use of natural regeneration [2]. Successful integration of natural regeneration in forest management is complex and requires thorough knowledge of ecological processes and their interactions with management. Problems with natural regeneration have been documented for decades in many regions in the world [3-5], but often without a clear explanation for the lack of regeneration success. Therefore, a better understanding of the bottlenecks in the regeneration process and factors influencing these bottlenecks is needed.

Although the lack of seeds or low seed quality can limit regeneration, post-dispersal factors such as the availability and quality of microsites, determined by, for instance, microclimatic conditions 
and soil properties, are important ecological filters controlling seedling establishment, survival and growth [6]. The forest canopy affects the biotic and abiotic conditions of the seedling environment, both aboveground and belowground. Aboveground, trees cast shade, moderate environmental extremes and thus alter the microenvironments experienced by seedlings [7-9]. Alterations in light conditions by trees are known to strongly affect seedling regeneration dynamics $[8,10,11]$. Belowground, trees affect seedlings directly by competing for nutrients and water [12-14], and indirectly by influencing the abundance of soil pathogens [15,16] and by modifying the biogeochemistry of the soil [17-19].

For most temperate tree species, seeds are released by the mother trees and land on the soil surface. Seedbed characteristics are thus important for the success of natural regeneration. Mineral soil is generally considered as a good seedbed because of its high water infiltration capacity, favourable aeration and good hydraulic contact between soil particles and seeds [20]. The forest floor, i.e., the organic layer on top of the mineral soil, is usually less suitable because it constitutes a physical barrier for seedlings by impeding penetration of radicles and thus preventing contact with the mineral soil [21]. However, the suitability of environmental conditions may change during the regeneration process and species' ecological preferences may differ from one life stage to the next [22]. Characteristics of the environment that are favourable to seeds may be unfavourable to seedlings. For example, environmental conditions that promote seed survival, germination and seedling establishment may also promote seedling herbivory, thereby negatively affecting seedling growth and survival [22].

Forest management can have an effect on both the mineral soil and the forest floor. By choosing tree species with different chemical litter characteristics, for instance, management choices lead to differences in decomposition rates, nutrient cycling and soil nutrient availability [17,23]. As tree species differ in their ability to establish and grow in the understorey plant community [24,25], tree species effects on understorey conditions can influence seedling dynamics and ultimately drive future stand composition. Furthermore, land-use history is another important determinant of the present-day forest conditions. For example, soils of forests on former agricultural fields generally have a higher $\mathrm{pH}$, higher nutrient concentrations and a lower organic matter content compared to soils of ancient forests, i.e., forests that have been continuously forested since at least the oldest available historical data [26]. In sum, studies on the factors that drive tree regeneration success need to account for these potential effects of tree species composition and land-use history.

In order to improve our understanding of how tree regeneration is affected by variation in tree species composition, we performed a field experiment within an existing research platform consisting of 53 forest plots varying in tree species diversity (one up to three tree species) and composition. The experiment focused on the effects of mineral soil and forest floor conditions on tree regeneration because these have been studied less than aboveground conditions such as light availability and might be equally important. All plots lie in ancient forests and on similar soils to avoid confounding effects of land-use history and soil type and to enable allocating differences in soil and forest floor conditions to differences in tree species composition. The research platform was designed around the plot-level presence and abundance of trees of three target species (pedunculate oak, beech and red oak); the experiment also looked at the regeneration of these target tree species. Our hypotheses were: (1) Naturally occurring soil and forest floor conditions have a negative effect on seedling establishment and performance, compared with optimal (potting soil) growing conditions, but the strength of the effects vary between tree species compositions; (2) The forest floor will have a more negative effect on seedling establishment compared to seedling performance; (3) The combined effects of the mineral soil and forest floor on seedling establishment and survival are more negative than the individual effects of the mineral soil and forest floor. 


\section{Materials and Methods}

\subsection{Study Area and Research Platform}

The TREEWEB platform (http:/ / www.treedivbelgium.ugent.be/pl_treeweb.html) is a network of 53 plots in mature forests in a $450 \mathrm{~km}^{2}$ window in northern Belgium [27]. The temperate climate is characterized by a mean annual temperature of $9.5^{\circ} \mathrm{C}$ and an annual precipitation of $726 \mathrm{~mm}$ distributed evenly over the year (1980-2010, Royal Meteorological Institute of Belgium). All the plots have a similar land-use history (continuously forested since at least 1850) and are located on a similar relatively dry, sandy loam soil. The plots are monocultures, two-species mixtures and three-species mixtures of three widely occurring and economically important tree species: pedunculate oak (Quercus robur L.), beech (Fagus sylvatica L.) and red oak (Quercus rubra L.). Pedunculate oak and beech are important for wood production in Western Europe and also harbour a high associated biodiversity (e.g., [28]). Red oak was introduced into Belgium in 1782 and was mainly planted in parks and along roads because of its esthetic qualities. From 1880 onwards, red oak has been increasingly used as a forest species because of its fast growth, large ecological amplitude and suitable wood properties [29]. Nowadays, red oak is often found in forests, i.e., it is the second most frequently occurring non-native tree species in northern Belgium, with the sixth most important standing stock volume [30]. As red oak is locally invasive, its impact on the forest ecosystem is thus of concern to both forest managers and policy makers. All possible combinations of the three target species were included in the platform: the three tree species were present as monocultures, in two-species mixtures as well as in the three-species mixture. A complete dilution design was thus avoided because increasing species diversity was not confounded with a decreasing abundance of one particular species, which makes it possible to distinguish between tree species identity and diversity effects (cf. [31]). The diversity in the plots was maximized by selecting forest stands with high evenness in the abundance of the tree species and avoiding mixtures with a strong monoculture signature caused by the more dominant species [27]. An admixture of non-target tree species was accepted as long as the summed basal area of the admixed species was less than $5 \%$ of the total basal area. The plots measured $30 \mathrm{~m} \times 30 \mathrm{~m}$ (Figure 1) and were surrounded by a buffer zone of $10 \mathrm{~m}$ wide with a similar forest composition and structure to avoid edge effects. For more detailed information on the plot selection criteria and the selected plots, see [27].

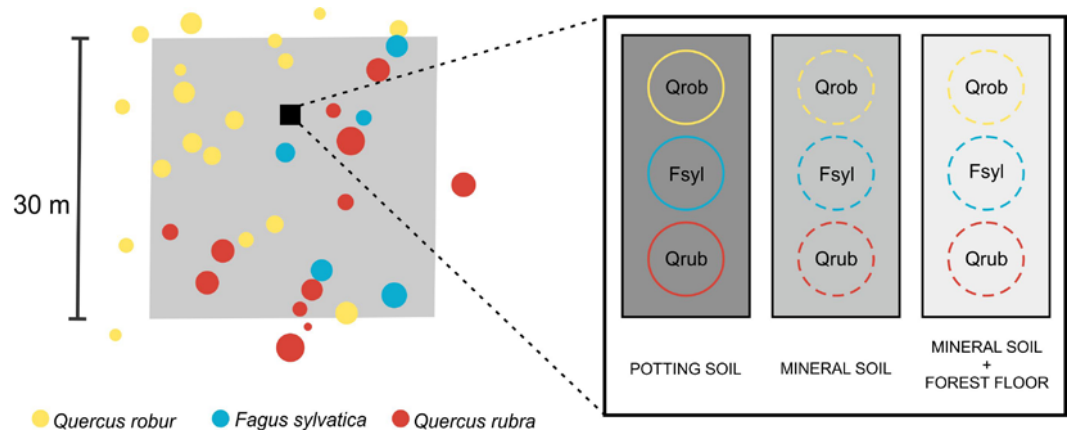

Figure 1. Detailed map of a typical plot in the TREEWEB platform (left, three species plot) and the experimental setup within such a plot (right). The grey square represents the $30 \mathrm{~m} \times 30 \mathrm{~m}$ plot; coloured dots represent trees (different colours for different tree species, different sizes showing diameter at breast height). The small black square indicates the location of the experiment within the plot, replicated across 50 plots. Seeds of Quercus robur L. (Qrob), Fagus sylvatica L. (Fsyl) and Quercus rubra L. (Qrub) were sown in pots filled with potting soil (POTTING SOIL), directly in the mineral soil after removing the forest floor (MINERAL SOIL), and on top of the present forest floor (MINERAL SOIL + FOREST FLOOR). The pots with potting soil were dug into the soil until the soil surface level was similar in and outside the pots. In the MINERAL SOIL and MINERAL SOIL + FOREST FLOOR treatments, the seeds were not sown in pots, but the surface area of the sowing space was similar to the surface area of the pots (dotted lines). 


\subsection{Regeneration Experiment}

The TREEWEB plots allowed setting up a field experiment in a carefully designed study platform for which many relevant environmental characteristics (e.g., soil and forest floor characteristics) were readily available. Soil and forest floor characteristics differed between the different tree species compositions [32]. The experiment was designed to study the effects of the mineral soil and the forest floor on the regeneration of pedunculate oak, beech and red oak, i.e., the target species of TREEWEB. The experiment involved three treatments: (1) POTTING SOIL representing optimal rooting conditions and nutrient supply, (2) MINERAL SOIL and (3) MINERAL SOIL + FOREST FLOOR to look at the effects of both the naturally occurring soil and forest floor. We installed the experiment in each of the TREEWEB plots in autumn 2015. We chose a location not too close to the plot edge where the canopy best resembled the intended species composition of the plot (Figure 1).

For the POTTING SOIL treatment, we filled plastic pots (diameter $30 \mathrm{~cm}$, height $20 \mathrm{~cm}$ ) with standard potting soil (potting soil type "LP114D" (Peltracom, Ghent, Belgium), pH 6, nitrogen:phosphorus:potassium 14:16:18, organic matter 87\%) and dug them into the soil until the soil surface level was similar in and outside the pots. For the MINERAL SOIL treatment, we carefully removed the entire forest floor (litter, fragmentation and humification layer) until the mineral soil was visible. For the MINERAL SOIL + FOREST FLOOR treatment, we left the forest floor intact. Per plot, we sowed in each treatment 25 seeds of pedunculate oak, 40 seeds of beech and 25 seeds of red oak in February-March 2016. We bought the seeds at a tree nursery and the seeds originated from Belgium (beech) and The Netherlands (both oak species). We only sowed seeds that seemed healthy based on a visual quality control. The beech seeds had been cold-stratified until dormancy break before sowing. For each species and treatment, the seeds were sown on a circular area with diameter $30 \mathrm{~cm}$ (cf. the pots of the potting soil) (Figure 1). We slightly pressed the seeds into the surface after sowing and covered them with a thin layer of locally present leaf litter to prevent drying out and to mimic the litterfall covering seeds after they are dropped in autumn. We removed understorey vegetation, if present, to prevent competition with the tree seedlings. We put a wire mesh (mesh size $0.5 \mathrm{~cm} \times 0.5 \mathrm{~cm}$ ) around each treatment to prevent seed predation by mice and other seed predators (see Figure A1). Due to problems with vandalism and waterlogging, the experiment could only be installed in 50 out of the 53 plots (see Table A1). Hence, in total, we sowed 13,500 seeds, i.e., 3750 seeds of pedunculate oak ( 25 seeds $\times 3$ treatments $\times 50$ plots), 6000 seeds of beech and 3750 seeds of red oak. To check the quality of the seeds, we also sowed 75 seeds of each species in ideal germination circumstances, i.e., the seeds were sown in pots filled with potting soil that were placed inside and watered twice a week. We observed germination of $80 \%$ for pedunculate oak, $63 \%$ for beech and $58 \%$ for red oak.

\subsection{Measurements}

To measure early establishment, we counted the number of seedlings at the beginning and end of the first growing season, i.e., in July and September 2016. In September 2016, we thinned the seedlings until a maximum of five seedlings per species and per treatment remained to prevent excessive competition between the seedlings during the second growing season. The remaining five seedlings were representative of the seedlings before thinning, i.e., we kept the smallest, the largest and some in-between seedlings. To measure seedling survival over winter and to quantify the performance of the surviving seedlings, we counted the seedlings again in September 2017, i.e., at the end of the second growing season, measured their height to the nearest $0.5 \mathrm{~cm}$ and harvested them to determine their biomass. We carefully excavated each individual seedling, washed it to remove soil particles and dried it for $24 \mathrm{~h}$ at $105^{\circ} \mathrm{C}$. We separated the above- and belowground plant parts and weighed them to the nearest $0.01 \mathrm{~g}$ to determine shoot biomass (aboveground woody parts and leaves) and root biomass (belowground parts).

The forest floor was sampled using a $25 \mathrm{~cm} \times 25 \mathrm{~cm}$ wooden frame, oven-dried at $65{ }^{\circ} \mathrm{C}$ and weighed to the nearest $0.01 \mathrm{~g}$. The forest floor biomass was calculated as the sum of the litter 
layer, consisting of recently fallen rather intact leaves, and the fragmentation and humification layer, containing the fragmented and (partly) decomposed leaves (cf. [33]). The mineral soil sampling was confined to the upper $10 \mathrm{~cm}$ of soil as tree species effects on soil properties were expected to be most clear there. Additionally, we sampled the upper $5 \mathrm{~cm}$ of soil with a Kopecky ring (diameter $5 \mathrm{~cm}$ ) for determination of soil bulk density. All soil samples were dried for at least $48 \mathrm{~h}$ at $40{ }^{\circ} \mathrm{C}$; samples for chemical analysis were sieved through a $1 \mathrm{~mm}$ mesh and samples for determination of bulk density were weighed to the nearest $0.01 \mathrm{~g}$. For the forest floor and soil samples, total nitrogen and carbon concentrations were measured by dry combustion using an elemental analyser (Vario Macro Cube, Elementar, Langenselbold, Germany). For the soil samples, exchangeable potassium, calcium, magnesium and aluminium concentrations were measured by atomic absorption spectrophotometry (AAS) (AA240FS Fast Sequential AAS, Agilent Technologies, Santa Clara, CA, USA) after extraction in $\mathrm{BaCl}_{2}$. We calculated the base cation concentrations in the soil by summing the equivalents of potassium, calcium and magnesium; the soil effective cation exchange capacity $\left(\mathrm{CEC}_{\mathrm{e}}\right)$ as the sum of potassium, calcium, magnesium and aluminium; and the soil base saturation (BS) as base cation concentration divided by $\mathrm{CEC}_{\mathrm{e}}$. The collection of the plot-level soil and forest floor data has been described in detail in [32].

\subsection{Data Analysis}

We focused on seedling establishment (early establishment after germination and survival after the second growing season) and performance (height, root and shoot biomass, and root:shoot ratio after the second growing season). We calculated early establishment for beech as the number of seedlings present in July 2016 divided by the number of seeds sown and for pedunculate and red oak as the number of seedlings present in September 2016 divided by the number of seeds sown. Pedunculate oak showed a later and more prolonged germination than beech, with higher numbers of seedlings in September as compared to July, while beech clearly had more seedlings in July than in September. For each plot, we calculated seedling survival per species and per treatment as the number of living seedlings in September 2017 divided by the number of seedlings after thinning in September 2016. For seedling height, root and shoot biomass, we calculated a plot-level average per species and per treatment. Root:shoot ratio was calculated by dividing the root biomass by the shoot biomass.

To quantify the effects of MINERAL SOIL and FOREST FLOOR on seedling establishment and performance, relative to the POTTING SOIL treatment, we calculated effect sizes, i.e., the natural logarithm of the proportional difference between the MINERAL SOIL (or MINERAL SOIL + FOREST FLOOR) treatment and the POTTING SOIL treatment. By calculating the effects of MINERAL SOIL and FOREST FLOOR relative to the POTTING SOIL in each plot, we filtered out effects of differences in aboveground environmental conditions among the plots (e.g., light availability, microclimate) caused by the differences in tree species composition. Therefore, the variation between plots originates from mineral soil and forest floor effects per se. In addition, working with effect sizes allowed comparing the three species, independently of the inherent differences in seed quality. Per plot, we calculated for each species and each response variable (early establishment, survival, height, root biomass, shoot biomass and root:shoot ratio) three effect sizes (ES). We first calculated the effect size that estimates the combined effect of mineral soil and forest floor $\left(\mathrm{ES}_{\mathrm{S}+\mathrm{F}}\right)$ and the effect size that estimates the effect of mineral soil only $\left(\mathrm{ES}_{\mathrm{S}}\right)$ :

$$
\begin{aligned}
\mathrm{ES}_{\mathrm{S}+\mathrm{F}} & =\ln \left(\mathrm{X}_{\mathrm{S}+\mathrm{F}} / \mathrm{X}_{\mathrm{P}}\right) \\
\mathrm{ES}_{\mathrm{S}} & =\ln \left(\mathrm{X}_{\mathrm{S}} / \mathrm{X}_{\mathrm{P}}\right)
\end{aligned}
$$

with $X$ as the response variable, measured in the POTTING SOIL treatment $(P)$, the MINERAL SOIL treatment $(S)$ and the MINERAL SOIL + FOREST FLOOR treatment $(S+F)$.

We then calculated the effect size that estimates the effect of forest floor only $\left(E S_{F}\right)$ as the difference between $\mathrm{ES}_{\mathrm{S}+\mathrm{F}}$ and $\mathrm{ES}_{\mathrm{S}}$ :

$$
\mathrm{ES}_{\mathrm{F}}=\mathrm{ES}_{\mathrm{S}+\mathrm{F}}-\mathrm{ES}_{\mathrm{S}}
$$


First, we looked at the overall effects of mineral soil and forest floor on seedling establishment and performance across the TREEWEB plots, by calculating the average ( $\pm 95 \%$ confidence interval) effect size per species and response variable across the 50 plots. Next, we investigated whether variation in the effect size across plots could be further explained by the measured (abiotic) properties of the soil and forest floor, which differed between tree species compositions. We used linear models to describe the relationship between the effect sizes and the different explanatory variables. For the effect size of the mineral soil $\left(\mathrm{ES}_{\mathrm{S}}\right)$, the explanatory variables we looked at were the soil $\mathrm{C} / \mathrm{N}$ (carbon/nitrogen) ratio, soil base saturation and soil bulk density. For the effect size of the forest floor $\left(\mathrm{ES}_{\mathrm{F}}\right)$, we used the $\mathrm{C} / \mathrm{N}$ ratio and biomass of the forest floor as explanatory variables. The explanatory variables were normalized before the analysis.

\section{Results}

Of the 13,500 seeds sown in February 2016, 4931 (i.e., 37\%) had germinated by July 2016 (Table 1). At the end of the first growing season, i.e., in September 2016, we counted 4808 living seedlings (i.e., $36 \%$ ). After thinning at the end of the first growing season, 1874 seedlings remained. At the end of the second growing season, 1162 (i.e., $62 \%$ ) of the seedlings that remained after thinning were still alive (Table 1). 
Table 1. Total number of seeds and seedlings of Quercus robur L. (Qrob), Fagus sylvatica L. (Fsyl) and Quercus rubra L. (Qrub) per treatment (POTTING SOIL, MINERAL SOIL, MINERAL SOIL + FOREST FLOOR) and in total, across the 50 plots.

\begin{tabular}{|c|c|c|c|c|c|c|c|c|c|c|c|c|}
\hline & \multicolumn{3}{|c|}{ POTTING SOIL } & \multicolumn{3}{|c|}{ MINERAL SOIL } & \multicolumn{3}{|c|}{ MINERAL SOIL + FOREST FLOOR } & \multicolumn{3}{|c|}{ Total } \\
\hline & Qrob & Fsyl & Qrub & Qrob & Fsyl & Qrub & Qrob & Fsyl & Qrub & Qrob & Fsyl & Qrub \\
\hline $\begin{array}{l}\text { seeds sown } \\
\quad \text {-February } 2016\end{array}$ & 1250 & 2000 & 1250 & 1250 & 2000 & 1250 & 1250 & 2000 & 1250 & 3750 & 6000 & 3750 \\
\hline $\begin{array}{l}\text { seedlings } \\
\text {-July } 2016\end{array}$ & 792 & 663 & 715 & 626 & 299 & 533 & 517 & 303 & 483 & 1935 & 1265 & 1731 \\
\hline -September 2016 & 902 & 465 & 751 & 736 & 149 & 515 & 644 & 163 & 483 & 2282 & 777 & 1749 \\
\hline $\begin{array}{l}\text {-September 2016, } \\
\text { after thinning }\end{array}$ & 250 & 210 & 250 & 250 & 97 & 240 & 242 & 110 & 225 & 742 & 417 & 715 \\
\hline -September 2017 & 159 & 167 & 217 & 96 & 58 & 145 & 97 & 72 & 151 & 352 & 297 & 513 \\
\hline
\end{tabular}


Early establishment ranged on average between 15\% (beech, MINERAL SOIL treatment) and $72 \%$ (pedunculate oak, POTTING SOIL treatment) and was higher for both oak species than for beech in all treatments (Table 2). Survival ranged on average between 38\% (pedunculate oak, MINERAL SOIL treatment) and 87\% (red oak, POTTING SOIL treatment) and was highest for red oak, followed by beech and lowest for pedunculate oak in all treatments. Height was on average between $13.9 \mathrm{~cm}$ (beech, MINERAL SOIL treatment) and $20.2 \mathrm{~cm}$ (red oak, POTTING SOIL treatment), with pedunculate oak and red oak showing similar, but greater heights than beech in all treatments. Root biomass was on average between $0.20 \mathrm{~g}$ (beech, MINERAL SOIL treatment) and $0.60 \mathrm{~g}$ (red oak, POTTING SOIL treatment), with red oak having the highest root biomass, and pedunculate oak and beech having a similar but lower root biomass in all treatments (Table 2). Shoot biomass ranged on average between $0.19 \mathrm{~g}$ (beech, MINERAL SOIL treatment) and $0.68 \mathrm{~g}$ (red oak, POTTING SOIL treatment) and was highest for red oak, followed by pedunculate oak and lowest for beech in all treatments (Table B1 in Appendix B). The root:shoot ratio ranged on average between 0.76 (red oak, MINERAL SOIL treatment) and 1.43 (beech, MINERAL SOIL + FOREST FLOOR treatment) (Table B1 in Appendix B).

Table 2. Mean values for early establishment (after one growing season), survival, height and root biomass (after two growing seasons) of the seedlings of Quercus robur L. (Qrob), Fagus sylvatica L. (Fsyl) and Quercus rubra L. (Qrub) in each treatment (POTTING SOIL, MINERAL SOIL, MINERAL SOIL + FOREST FLOOR), with standard deviation in parentheses. The range of values for each variable is presented below the mean and standard deviation Letters indicate differences between species (Analysis of variance (ANOVA), Tukey post-hoc test, $p<0.05$ ).

\begin{tabular}{|c|c|c|c|}
\hline Seedling Characteristic & Qrob & Fsyl & Qrub \\
\hline \multicolumn{4}{|l|}{ Early establishment (\%) } \\
\hline POTTING SOIL & $\begin{array}{c}72.16(15.81)^{\mathrm{a}} \\
\quad(20-96)\end{array}$ & $\begin{array}{c}33.15(13.67)^{\mathrm{c}} \\
(0-57.5)\end{array}$ & $\begin{array}{c}60.08(15.17)^{\mathrm{b}} \\
\quad(32-88)\end{array}$ \\
\hline MINERAL SOIL & $\begin{array}{c}58.88(16.86)^{\mathrm{a}} \\
\quad(24-96)\end{array}$ & $\begin{array}{c}14.95(12)^{\mathrm{c}} \\
(0-42.5)\end{array}$ & $\begin{array}{c}41.2(17.36)^{b} \\
(8-84)\end{array}$ \\
\hline MINERAL SOIL + FOREST FLOOR & $\begin{array}{c}51.52(20.39)^{\mathrm{a}} \\
(4-92)\end{array}$ & $\begin{array}{c}15.15(12.19)^{\mathrm{c}} \\
(0-52.5)\end{array}$ & $\begin{array}{c}38.64(20.58)^{b} \\
\quad(0-100)\end{array}$ \\
\hline \multicolumn{4}{|l|}{ Survival (\%) } \\
\hline POTTING SOIL & $\begin{array}{c}63.6(25.46)^{\mathrm{b}} \\
(20-100)\end{array}$ & $\begin{array}{c}76.34(29.83)^{\mathrm{a}} \\
\quad(0-100)\end{array}$ & $\begin{array}{c}86.8(17.43)^{\mathrm{a}} \\
\quad(40-100)\end{array}$ \\
\hline MINERAL SOIL & $\begin{array}{c}38.4(26.45)^{b} \\
(0-100)\end{array}$ & $\begin{array}{c}52.97(44.14)^{a b} \\
(0-100)\end{array}$ & $\begin{array}{c}60.3(31.23)^{\mathrm{a}} \\
\quad(0-100)\end{array}$ \\
\hline MINERAL SOIL + FOREST FLOOR & $\begin{array}{c}40.6(28.74)^{b} \\
\quad(0-100)\end{array}$ & $\begin{array}{c}56.78(40.45)^{\mathrm{ab}} \\
\quad(0-100)\end{array}$ & $\begin{array}{c}67.21(36.5)^{\mathrm{a}} \\
\quad(0-100)\end{array}$ \\
\hline \multicolumn{4}{|l|}{ Height (cm) } \\
\hline POTTING SOIL & $\begin{array}{c}19.23(4.59)^{\mathrm{a}} \\
\quad(10-31)\end{array}$ & $\begin{array}{c}15.83(4.17)^{\mathrm{b}} \\
(7.5-29.1)\end{array}$ & $\begin{array}{c}20.19(2.82)^{\mathrm{a}} \\
(13-26.17)\end{array}$ \\
\hline MINERAL SOIL & $\begin{array}{c}17.22(4.46)^{\mathrm{a}} \\
\quad(7.5-25)\end{array}$ & $\begin{array}{c}13.88(4.03)^{b} \\
\quad(8-23.1)\end{array}$ & $\begin{array}{c}18.63(4.61)^{\mathrm{a}} \\
\quad(8-30.7)\end{array}$ \\
\hline MINERAL SOIL + FOREST FLOOR & $\begin{array}{c}16.24(5.17)^{a} \\
\quad(6-28)\end{array}$ & $\begin{array}{c}14.92(2.84)^{\mathrm{a}} \\
\quad(11-24.7)\end{array}$ & $\begin{array}{c}17.19(4.46)^{\mathrm{a}} \\
\quad(9-29.8)\end{array}$ \\
\hline \multicolumn{4}{|l|}{ Root biomass (g) } \\
\hline POTTING SOIL & $\begin{array}{c}0.35(0.12)^{b} \\
(0.19-0.91)\end{array}$ & $\begin{array}{c}0.29(0.21)^{b} \\
(0.04-1.01)\end{array}$ & $\begin{array}{l}0.6(0.33)^{\mathrm{a}} \\
(0.21-1.62)\end{array}$ \\
\hline MINERAL SOIL & $\begin{array}{c}0.24(0.09)^{b} \\
(0.08-0.44)\end{array}$ & $\begin{array}{l}0.2(0.15)^{b} \\
(0.02-0.56)\end{array}$ & $\begin{array}{c}0.39(0.29)^{\mathrm{a}} \\
(0.06-1.86)\end{array}$ \\
\hline MINERAL SOIL + FOREST FLOOR & $\begin{array}{c}0.29(0.09)^{b} \\
(0.17-0.51)\end{array}$ & $\begin{array}{c}0.26(0.16)^{b} \\
(0.07-0.68)\end{array}$ & $\begin{array}{c}0.46(0.26)^{\mathrm{a}} \\
(0.19-1.18)\end{array}$ \\
\hline
\end{tabular}




\subsection{Effects of Mineral Soil and Forest Floor}

The treatment MINERAL SOIL + FOREST FLOOR generally had a negative effect on seedling establishment and performance, relative to the POTTING SOIL treatment (Figure 2). The early establishment was $35 \%$ (i.e., $\left.\exp \left(\mathrm{ES}_{\mathrm{S}+\mathrm{F}}\right)=\exp (-0.43)=0.65\right)$ lower than in the potting soil for pedunculate oak, $62 \%$ for beech and $43 \%$ for red oak. Survival was $31 \%$ lower than in the potting soil for pedunculate oak and $22 \%$ for red oak (non-significant decrease for beech). Height was $17 \%$ lower than in the potting soil for both oak species and $16 \%$ for beech. Root biomass was $21 \%$ lower than in the potting soil for pedunculate oak and 29\% for red oak (non-significant decrease for beech). Shoot biomass was 15\% lower than in the potting soil for pedunculate oak, 35\% for beech and $30 \%$ for red oak (Figure B1 in Appendix B). The root:shoot ratio of the three species was not significantly affected by the MINERAL SOIL + FOREST FLOOR treatment relative to the POTTING SOIL treatment (Figure B1 in Appendix B).

The negative MINERAL SOIL + FOREST FLOOR effect was mainly due to a significant and negative MINERAL SOIL effect. This was found for the early establishment, survival, height and the root and shoot biomass of the seedlings of all three species (Figures 2 and B1 in Appendix B), for which the effect sizes were in general in the same order of magnitude as those of MINERAL SOIL + FOREST FLOOR. The root:shoot ratio was negatively affected by MINERAL SOIL and was 30\% lower than in the potting soil for pedunculate oak and 16\% lower for red oak (non-significant decrease for beech).
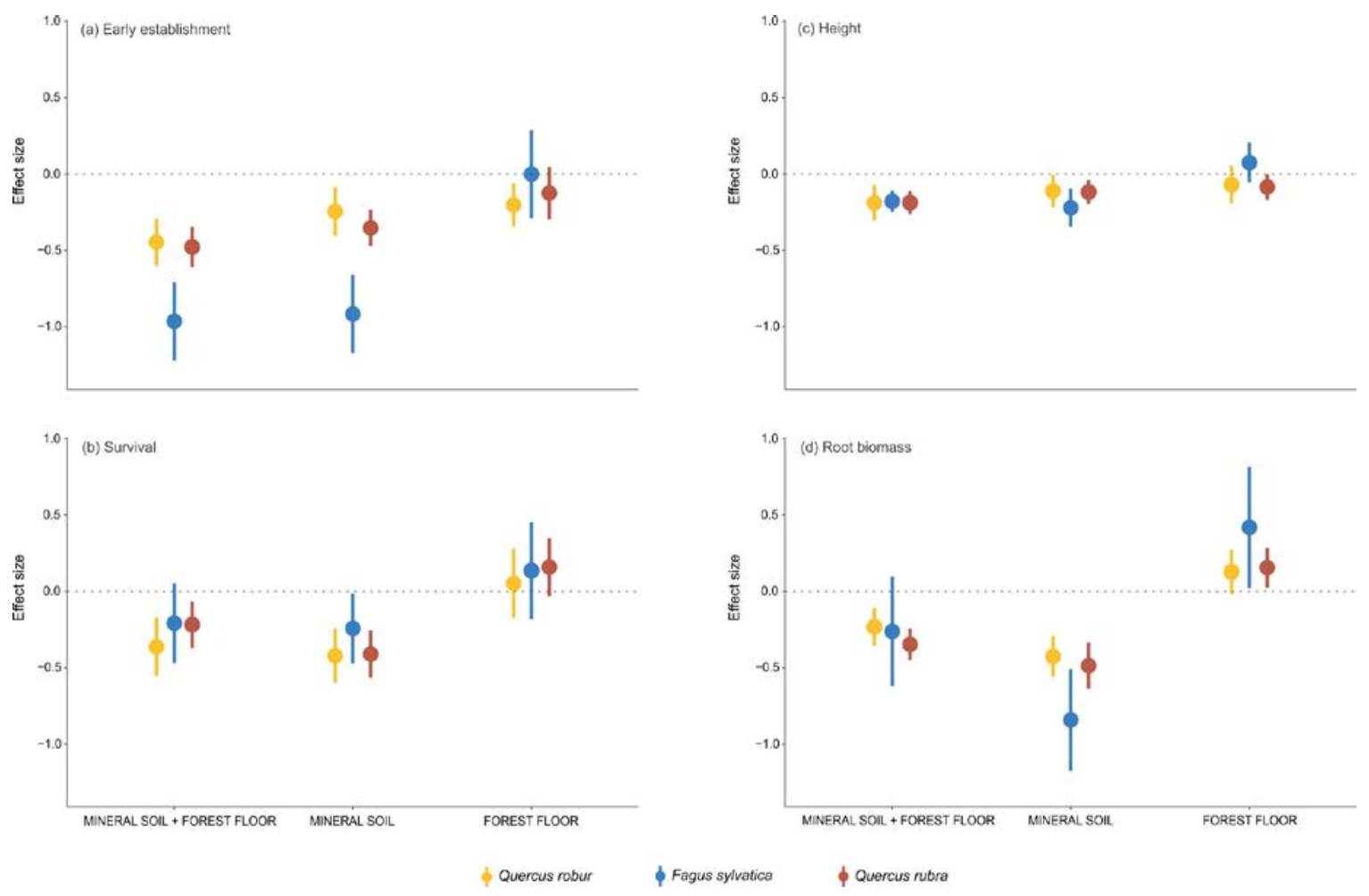

Figure 2. The effects of MINERAL SOIL + FOREST FLOOR and MINERAL SOIL only (relative to the POTTING SOIL treatment) and FOREST FLOOR only (calculated as the difference between MINERAL SOIL + FOREST FLOOR and MINERAL SOIL) on seedling establishment ((a) early establishment; (b) survival) and performance ((c) height, (d) root biomass). For each of the three tree species, the mean effect size (see Section 2.4) for the 50 plots is shown, with the $95 \%$ confidence interval. The dotted line indicates no effect, i.e., an effect size of zero.

The effects of the FOREST FLOOR were in most cases not significantly different from zero (Figure 2). Only the early establishment of pedunculate oak showed a small negative effect, while the 
root biomass of beech and red oak showed a small positive effect (Figure 2). The shoot biomass of beech showed a small positive effect, and the root:shoot ratio of both oak species increased by $24 \%$ and $19 \%$ when the forest floor was present (Figure B1 in Appendix B).

\subsection{Effects of Specific Soil and Forest Floor Properties}

In general, the variation in the effects of MINERAL SOIL as well as the effects of FOREST FLOOR on seedling establishment and performance were only weakly related to the investigated soil and forest floor properties. No consistent patterns emerged for a specific species or measure of seedling establishment or performance. For pedunculate oak, the negative effects of MINERAL SOIL on seedling survival were less strong when the soil $\mathrm{C} / \mathrm{N}$ ratio and soil base saturation increased (Figure $3 \mathrm{a}, \mathrm{b}$ ), while the root:shoot ratio decreased more strongly with increasing soil base saturation (Figure B2b in Appendix B). For beech, none of the measured soil properties showed a significant relationship with the negative effects of MINERAL SOIL. For red oak, the early establishment, height and shoot biomass were more strongly negatively affected with increasing soil C/N ratio (Figure 3a, Figure B2a in Appendix B), and the negative effect on root biomass became stronger with increasing soil bulk density (Figure 3c).
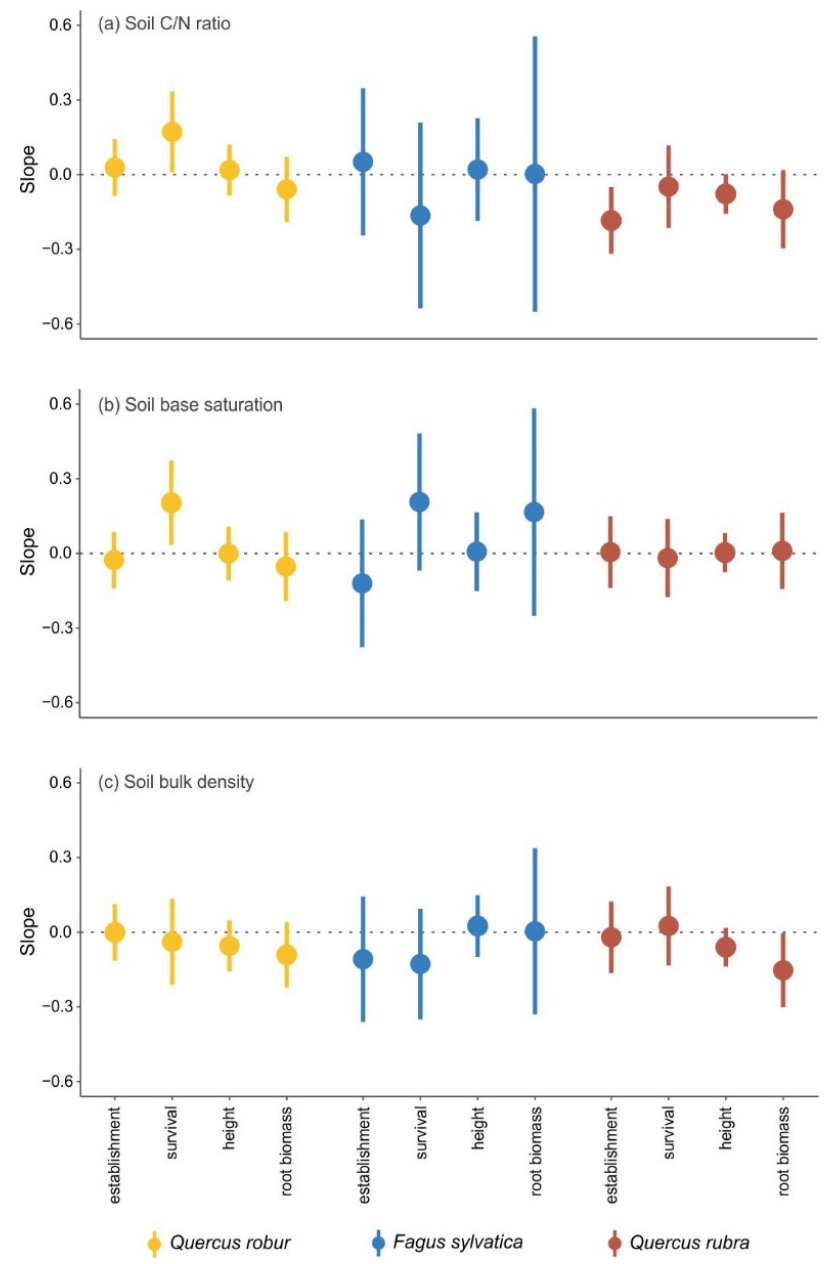

Figure 3. The relationship between the effect of MINERAL SOIL on seedling establishment and performance on the one hand, and the $\mathrm{C} / \mathrm{N}$ ratio (a), base saturation $(\mathbf{b})$ and bulk density $(\mathbf{c})$ of the soil on the other hand. For each of the three species, the estimated slopes for the relationship between the plot-level effect sizes of the MINERAL SOIL and the different soil properties are shown with their $95 \%$ confidence interval. The dotted line indicates a slope of zero, i.e., no relationship between effect sizes and soil properties. 
The FOREST FLOOR effect became less negative with increasing litter $\mathrm{C} / \mathrm{N}$ ratio for the survival of pedunculate oak (Figure 4a), but more negative with increasing litter $\mathrm{C} / \mathrm{N}$ ratio for the establishment of beech (Figure 4a). For red oak, the positive effect on root biomass became stronger with increasing litter $\mathrm{C} / \mathrm{N}$ ratio (Figure $4 \mathrm{a}$ ), the effect on shoot biomass became less negative with increasing litter $\mathrm{C} / \mathrm{N}$ ratio (Figure B3a in Appendix B), and the positive effect on the root:shoot ratio became stronger with increasing litter biomass (Figure B3b in Appendix B).
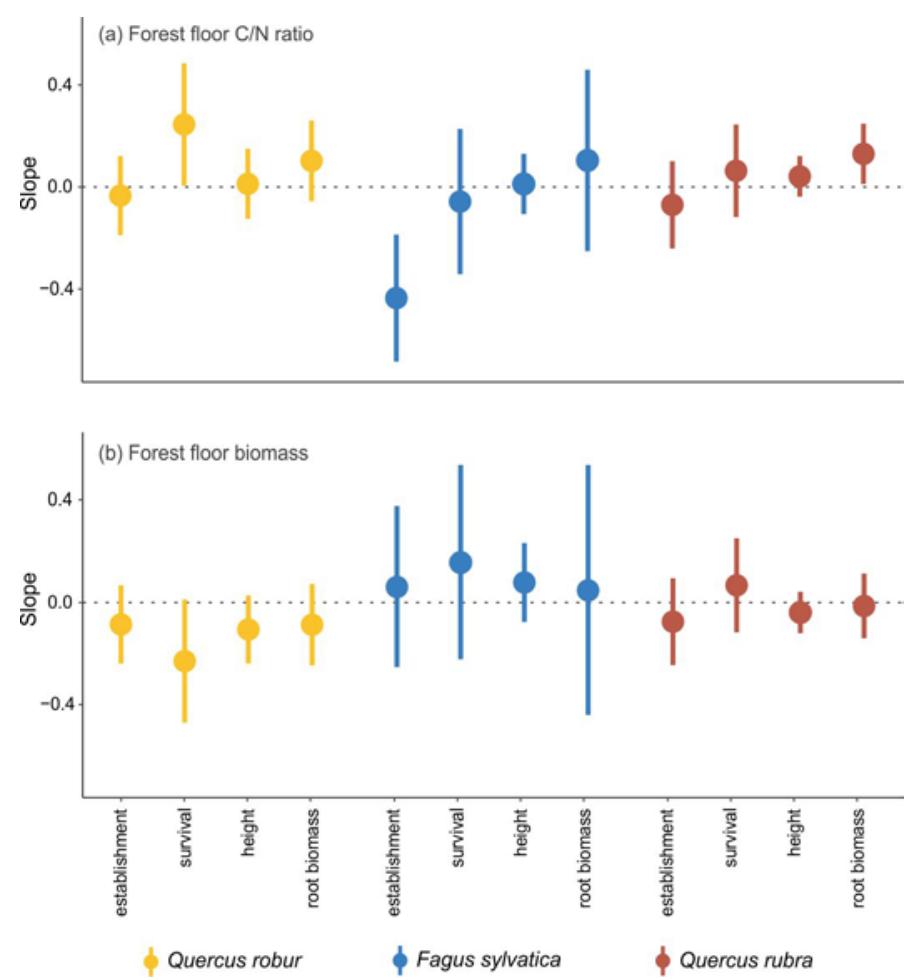

Figure 4. The relationship between the effect of FOREST FLOOR on seedling establishment and performance on the one hand, and the $\mathrm{C} / \mathrm{N}$ ratio (a) and biomass (b) of the forest floor on the other hand. For each of the three species, the estimated slopes for the relationship between the plot-level effect sizes of the FOREST FLOOR and the different forest floor properties are shown with their $95 \%$ confidence interval. The dotted line indicates a slope of zero, i.e., no relationship between effect sizes and forest floor properties.

\section{Discussion}

The degree to which soil conditions limit regeneration varied between the three studies species and during the regeneration process: for pedunculate oak, soil effects caused the second growing season to be the main bottleneck, while the opposite was true for beech, i.e., the first growing season most limited regeneration. The strength of the soil effect could not be further explained by soil properties such as the $\mathrm{C} / \mathrm{N}$ ratio, base saturation and bulk density. Furthermore, the forest floor did not deteriorate or mitigate the negative soil effects. Below we elaborate on the species-specific differences in early establishment and survival and try to explain the observed effects of the mineral soil and forest floor.

\subsection{Species-Specific Differences in Early Establishment and Survival}

The differences in early establishment between the species might be partially explained by differences in the quality of the seeds we used (germination under controlled conditions was $80 \%$ for pedunculate oak, $63 \%$ for beech and $58 \%$ for red oak). The early establishment in the field (Table 2) was lower than these germination rates but showed the same trend for both oak species, i.e., higher 
establishment success for pedunculate oak (61\%) compared to red oak (47\%). For beech, the early establishment success in the field (21\%) was disproportionally low compared to the germination rates, which suggests that seed quality was not the only limiting factor. The lower establishment success of beech compared to both oak species might be related to the lower amount of nutrient reserves in the seeds of beech. Nutrient reserves in seeds are important for initial root growth, and large seeds usually store large amounts of nutrients and sustain young seedlings better during environmental stresses than do small seeds [34,35]. For the beech seedlings, we indeed saw 38\% mortality of the initially established seedlings between June and September of the first growing season (Table 1), which might be caused by a fast depletion of nutrient reserves, an insufficient initial root growth and insufficient development of aboveground biomass to sustain the individuals via photosynthesis. Light availability probably played a minor role in explaining the differences in early establishment between the species since first-year seedlings of oak and beech are equally capable of surviving under low light conditions [36,37].

The survival during the second growing season decreased in the order red oak-beech-pedunculate oak (Table 2). The differences in survival between the species are unlikely to be related to the differences in seed mass since nutrient reserves from large seeds such as acorns are mainly used during the year of seedling emergence and are exhausted by the end of the first growing season [38]. Differences in shade and drought tolerance might have played a role in the seedling survival of the three species. Pedunculate oak is the least shade-tolerant of the study species [39,40], which might explain its low survival. Although beech is the most shade-tolerant of the study species $[39,40]$, with red oak classified as intermediate [41], beech is also the species that is most sensitive to drought [40], which may have had a negative impact on its seedling survival and may explain the lower survival of beech compared to red oak. Between May and September 2017, i.e., the second growing season, the total amount of precipitation was $302 \mathrm{~mm}$ and the average temperature was $17.1{ }^{\circ} \mathrm{C}$, which is drier and warmer, respectively, than the long-term average during that period $\left(360 \mathrm{~mm}, 16.2^{\circ} \mathrm{C}\right)$. Lower survival rates of less shade-tolerant pedunculate oak seedlings compared to more shade-tolerant beech seedlings have previously been reported [42].

\subsection{Negative Effect of Mineral Soil}

The mineral soil had a clear negative effect on the establishment and performance of the seedlings of the three species, relative to the potting soil. The effect of mineral soil on early establishment was clearly more negative for beech than for both oak species, which might again be related to the differences in nutrient reserves in the seeds. Beech seedlings already need soil resources during the first growing season (i.e., strongest soil effect on early establishment), while oak seedlings only become independent of the nutrient reserves during the second growing season due to higher initial seed reserves (i.e., strongest soil effect on survival). Also, for seedling height and root biomass, the negative effect of mineral soil was stronger for beech than for both oak species. In all species, the root biomass was more strongly negatively affected than seedling height.

The negative effect of mineral soil on the establishment and performance of the seedlings of our study species is likely due to a combination of abiotic and biotic properties of the mineral soil. Major differences between the mineral soil treatment and the potting soil treatment were probably (1) the availability of nutrients and water, (2) the penetrability of the growth medium for root development, and (3) the abundance of soil pathogens. Nutrient and water availability are likely to be lower in the mineral soil compared to the potting soil since potting soil is developed for efficient delivery of nutrients and water to plants. Moreover, the more dense structure of the mineral soil is likely to be less easily penetrable by roots than the potting soil. In addition, root competition with trees and understorey species in the mineral soil probably reduced the seedlings' access to the available nutrients and water, while the physical presence of a pot in the potting soil treatment probably secured seedlings' access to these resources. Previous studies indeed highlighted the importance of sufficient nutrient and water availability for successful seedling establishment and growth $[43,44]$. The mineral soil likely contained more pathogens than the potting soil, which could be disadvantageous for seedling 
establishment and performance. Increased seedling mortality with increasing abundance of soil pathogens has indeed been found [15]. In sum, the lower nutrient availability, the lower nutrient and water accessibility, the denser structure and the higher abundance of soil pathogens in the mineral soil compared to the potting soil may be the major factors responsible for the negative effect of the mineral soil.

While we did not measure water availability or pathogen abundance, we did look at the potential impact of chemical and physical soil properties [32] that are relevant for seedling establishment and performance: (1) the soil $\mathrm{C} / \mathrm{N}$ ratio, which is often used as a measure of soil quality and indicates the ability of a soil to provide nitrogen [45], (2) soil base saturation, which reflects the availability of exchangeable cations to plants [46], and (3) soil bulk density, which represents the physical resistance experienced by newly emerging roots [47]. However, we did not find changes in the negative impact of mineral soil on seedling establishment and performance along gradients in these soil properties in our study. It is likely that the measured soil properties did not differ sufficiently among the plots to cause strong differences in seedling responses. Soil nutrient availability has been shown to be affected by tree species composition, through species and diversity effects on litter decomposition rates and thus nutrient release [17-19]. However, our three study species, the main tree species of the TREEWEB platform, have a similar and relatively low leaf litter quality [32,48], and tree species composition effects on soil properties were limited within the platform [32]. Even though base saturation and soil bulk density showed significant differences between the different tree species, the range of these soil conditions might be too small to show clear effects on the seedlings of these tree species. Only for a few combinations of tree species and seedling characteristics did we find a relationship between the investigated soil properties and the observed negative effects of the mineral soil. The higher the base saturation, the smaller the negative effect of the mineral soil on the survival of pedunculate oak, and the lower the soil bulk density, the smaller the negative effect on the root biomass of red oak. Reduction of seedling growth with increasing soil bulk density was also found by [49] for Pinus radiata D. Don seedlings, whereas [50] found a tendency for deeper roots of pedunculate oak seedlings in a treatment with a lower soil bulk density.

\subsection{No Effects of Forest Floor}

Despite the wide-reaching effects of forest floors on the environment in which seedlings establish and grow [51], in our study, only the early establishment of pedunculate oak seedlings was negatively affected by the presence of the forest floor. However, forest floor properties such as $\mathrm{C} / \mathrm{N}$ ratio or forest floor biomass could not be linked with this negative effect. Even though the mean forest floor effect on the early establishment of beech was close to zero (Figure 2a), its negative relationship with the litter $\mathrm{C} / \mathrm{N}$ ratio indicates that the effect of forest floor on establishment ranges from positive at a low $\mathrm{C} / \mathrm{N}$ ratio to negative at a high $\mathrm{C} / \mathrm{N}$ ratio and thus under lower nitrogen availability (Figure 4a). This could indicate that beech seedlings may benefit from the presence of a forest floor as long as the nitrogen availability is high enough. The input of nutrients from decomposing litter has indeed been shown to increase seedling survival and growth [52]. Other studies showed that the presence of a forest floor may enhance seedling establishment of some species by maintaining a sufficiently humid microenvironment and preventing desiccation [53], whereas seedlings of many species are negatively affected by the forest floor since the forest floor can act as a physical barrier [54] and can possibly release toxic metabolites [55]. The microclimate maintained by the forest floor may be favorable to herbivores and pathogens, increasing the risk of fungal infection [56] and thus indirectly affecting seedling survival and performance.

The presence of the forest floor had a positive effect on the root biomass of the three species, although this effect was not significant for pedunculate oak. For red oak, this positive effect further increased with increasing forest floor $\mathrm{C} / \mathrm{N}$ ratio and thus decreasing nitrogen availability. This is in contrast with the study of [57], who found that red oak regeneration was optimal in locations with higher nitrogen concentrations. Root exploitation of the forest floor has been frequently observed 
and can be seen as a strategy to acquire nutrients more efficiently than from the mineral soil [58]. Physico-chemical properties of the forest floor influence the suitability for root development. Litter in an advanced decomposition stage has a rather dense structure [59], is characterised by a high water retention [60] and is advanced to the stage of net nutrient mineralisation [61]. The release of nutrients from decomposing litter and the good structure and water retention capacity of the forest floor may explain the positive effects of the forest floor on the root biomass of the seedlings in this study.

\section{Conclusions}

The design of the experiment in this study allowed us to focus on the effects of mineral soil and forest floor on seedling establishment and performance without confounding effects of aboveground environmental conditions, competing vegetation and seed predation. Seed quality was an important determinant for the success of natural regeneration. Creating bare soil was not enough to promote seedling establishment and performance, and the effects of the forest floor were limited in our forests. Differences in soil and forest floor properties between the different tree species compositions were too limited to result in strong differences in seedling establishment and performance. We found some evidence that improving soil properties is likely to be advantageous for the success of natural regeneration, e.g., the survival of pedunculate oak seedlings increased with increasing soil base saturation and the height of red oak seedlings increased with decreasing $\mathrm{C} / \mathrm{N}$ ratio and thus increasing nitrogen availability. However, the relative small gradient in soil properties in the studied forests did not allow us to draw strong conclusions. However, a larger gradient in mineral soil and forest floor conditions than the one in our study should be used to further investigate the driving factors behind the mineral soil and forest floor effects on seedling establishment and performance.

Acknowledgments: We thank the forest owners and the Flemish Forest and Nature Agency (ANB) for their kind cooperation in providing access to all the forest stands under study. We also thank Robbe De Beelde, Kris Ceunen and Luc Willems for their help with the installation of the experiment and the measurements, and Lionel Hertzog for his valuable comments on the article. Financial support for this research was provided via the UGent GOA project Scaling up Functional Biodiversity Research: from Individuals to Landscapes and Back (TREEWEB).

Author Contributions: A.M., D.B., L.L. and K.V. conceived and designed the study; S.R.E.D.G. performed the experiments; S.R.E.D.G. and L.B. analyzed the data; S.R.E.D.G., M.V., L.B., M.M.C. and K.V. wrote the paper.

Conflicts of Interest: The authors declare no conflict of interest. 


\section{Appendix A. Experimental Setup}

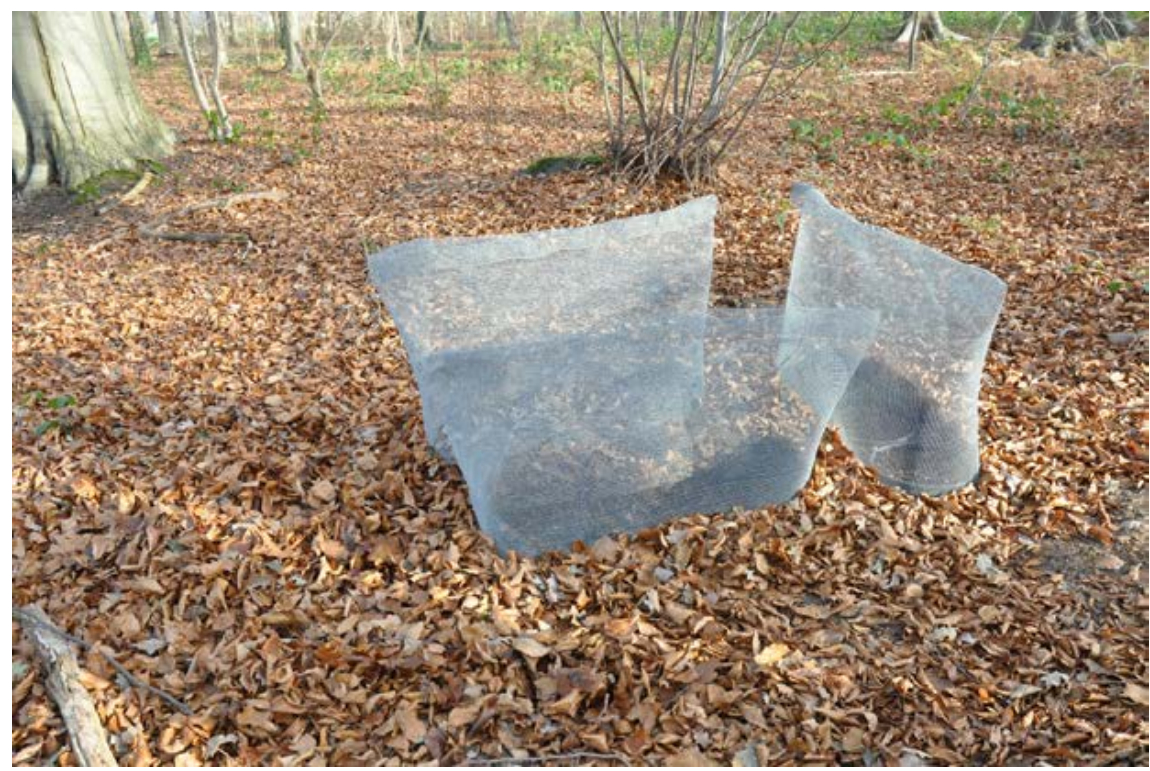

Figure A1. Picture of the regeneration experiment in the field. The three cages contain the three treatments within a plot: (1) POTTING SOIL representing optimal rooting conditions and nutrient supply, (2) MINERAL SOIL and (3) MINERAL SOIL + FOREST FLOOR to determine the effects of both the naturally occurring soil and forest floor. For the POTTING SOIL treatment, we filled plastic pots with standard potting and dug them into the soil until the soil surface level was similar in and outside the pots. For the MINERAL SOIL treatment, we carefully removed the entire forest floor (litter, fragmentation and humification layer) until the mineral soil was visible. For the MINERAL SOIL + FOREST FLOOR treatment, we left the forest floor intact. We sowed in each treatment 25 seeds of pedunculate oak, 40 seeds of beech and 25 seeds of red oak. The seeds were sown on a circular area with diameter $30 \mathrm{~cm}$ (cf. the pots of the potting soil) (Figure 1). We put a wire mesh (mesh size $0.5 \mathrm{~cm} \times 0.5 \mathrm{~cm}$ ) around each treatment to prevent seed predation by mice and other predators.

Table A1. The number of plots in which the regeneration experiment was installed per tree species composition with Quercus robur L. (Qrob), Fagus sylvatica L. (Fsyl) and Quercus rubra L. (Qrub).

\begin{tabular}{cc}
\hline Tree Species Composition & Number of Plots \\
\hline Qrob & 8 \\
Fsyl & 8 \\
Qrub & 8 \\
Qrob-Fsyl & 7 \\
Qrob-Qrub & 8 \\
Qrub-Fsyl & 6 \\
Qrob-Fsyl-Qrub & 5 \\
\hline
\end{tabular}




\section{Appendix B. Shoot Biomass and Root:Shoot Ratio Results}

Table B1. Mean values for shoot biomass and root:shoot ratio of the seedlings of Quercus robur (Qrob), Fagus sylvatica (Fsyl) and Quercus rubra (Qrub) in each treatment (POTTING SOIL, MINERAL SOIL, MINERAL SOIL + FOREST FLOOR), with standard deviation in parentheses. The range of values for each variable is presented below the mean and standard deviation. Letters indicate differences between species (ANOVA, Tukey post-hoc test, $p<0.05$ ).

\begin{tabular}{lccc}
\hline \multicolumn{1}{c}{ Seedling Characteristic } & Qrob & Fsyl & Qrub \\
\hline Shoot biomass (g) & & & \\
POTTING SOIL & $0.35(0.13)^{\mathrm{b}}$ & $0.27(0.17)^{\mathrm{b}}$ & $0.68(0.26)^{\mathrm{a}}$ \\
& $(0.14-0.77)$ & $(0.07-0.81)$ & $(0.26-1.37)^{\mathrm{a}}$ \\
MINERAL SOIL & $0.31(0.13)^{\mathrm{b}}$ & $0.19(0.15)^{\mathrm{b}}$ & $0.54(0.29)^{\mathrm{a}}$ \\
& $(0.14-0.64)$ & $(0.02-0.51)$ & $(0.09-1.96)^{\mathrm{b}}$ \\
MINERAL SOIL + FOREST FLOOR & $0.31(0.14)^{\mathrm{b}}$ & $0.23(0.17)^{\mathrm{b}}$ & $0.53(0.27)^{\mathrm{a}}$ \\
& $(0.11-0.75)$ & $(0.04-0.89)$ & $(0.19-1.16)$ \\
\hline Root:shoot ratio & & & \\
POTTING SOIL & $1.12(0.33)^{\mathrm{a}}$ & $1.19(0.51)^{\mathrm{a}}$ & $0.89(0.22)^{\mathrm{b}}$ \\
& $(0.64-2.3)$ & $(0.3-2.55)$ & $(0.4-1.54)^{\mathrm{b}}$ \\
MINERAL SOIL & $0.81(0.26)^{\mathrm{b}}$ & $1.25(0.79)^{\mathrm{a}}$ & $0.76(0.3)^{\mathrm{b}}$ \\
& $(0.39-1.49)$ & $(0.25-3.86)$ & $(0.39-1.79)$ \\
MINERAL SOIL + FOREST FLOOR & $1.06(0.41)^{\mathrm{b}}$ & $1.43(0.81)^{\mathrm{a}}$ & $0.91(0.27)^{\mathrm{b}}$ \\
& $(0.41-2.29)$ & $(0.27-3.86)$ & $(0.53-1.66)$ \\
\hline
\end{tabular}
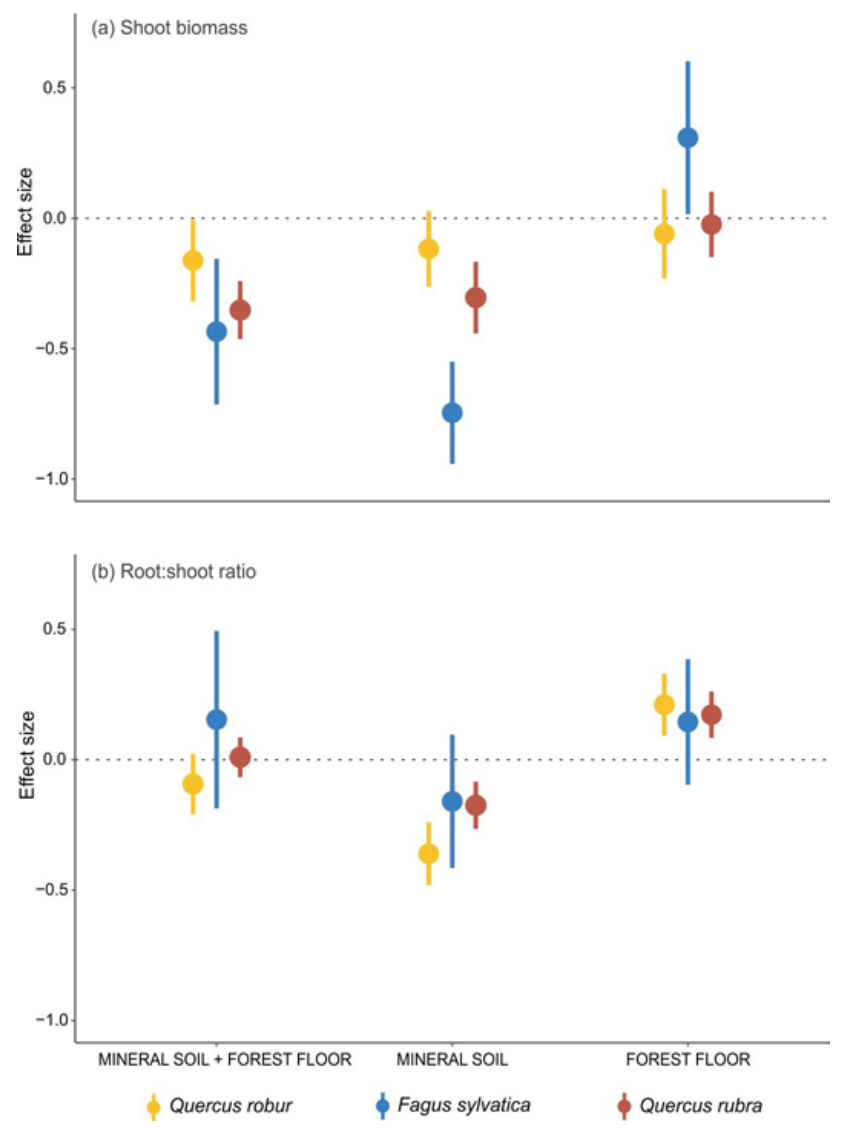

Figure B1. The effects of MINERAL SOIL + FOREST FLOOR and MINERAL SOIL only (relative to the POTTING SOIL treatment) and FOREST FLOOR only (calculated as the difference between MINERAL SOIL + FOREST FLOOR and MINERAL SOIL) on (a) shoot biomass and (b) root:shoot ratio. For each of the three tree species, the mean effect size (see Section 2.4) for the 50 plots is shown, with $95 \%$ confidence interval. The dotted line indicates no effect, i.e., an effect size of zero. 

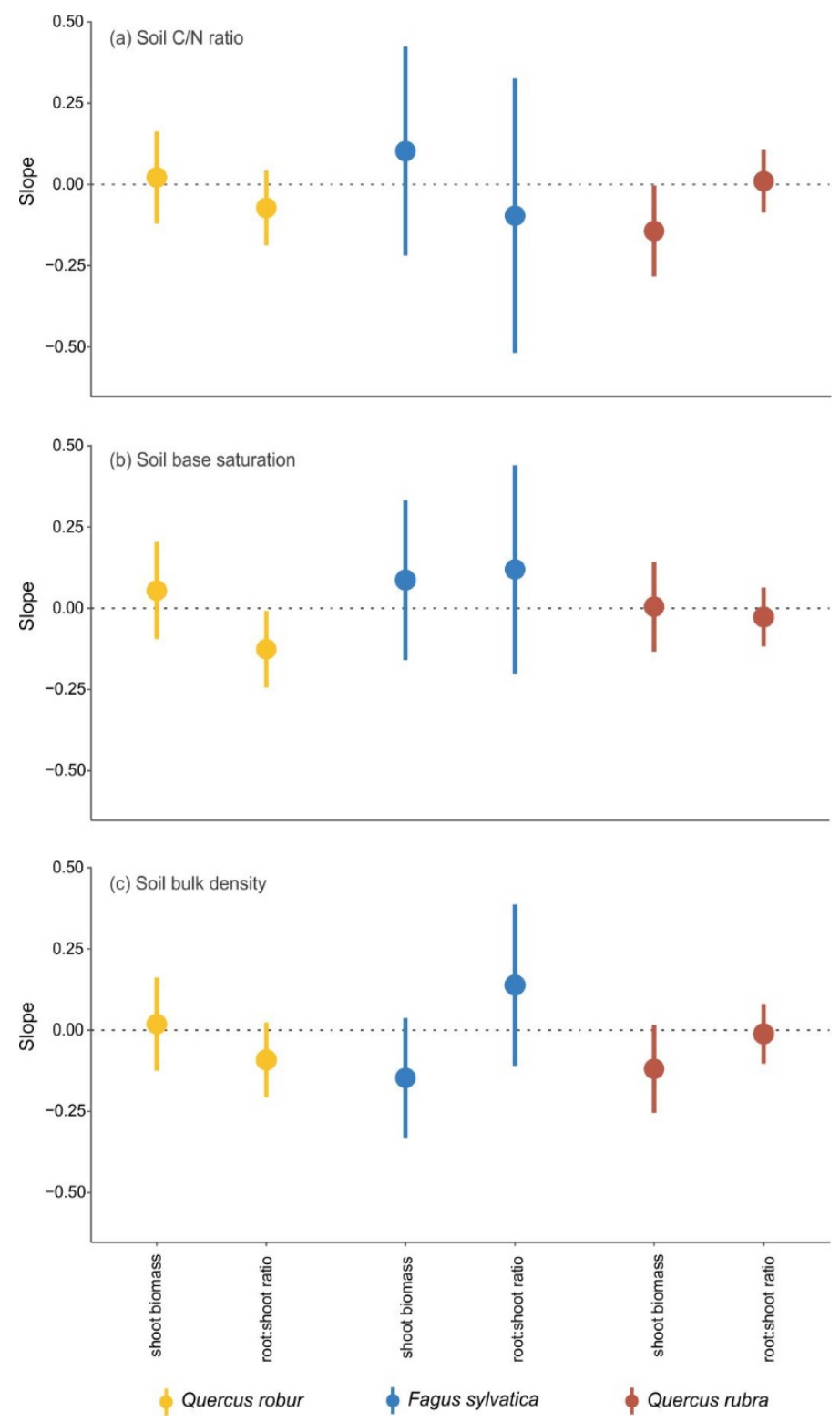

Figure B2. The relationship between the effect of MINERAL SOIL on seedling shoot biomass and root:shoot ratio on the one hand, and the $\mathrm{C} / \mathrm{N}$ ratio (a), base saturation (b) and bulk density (c) of the soil on the other hand. For each of the three species, the estimated slopes for the relationship between the effect sizes of the MINERAL SOIL and the different soil properties are shown with their 95\% confidence interval. The dotted line indicates a slope of zero, i.e., no relationship between effect sizes and soil properties. 

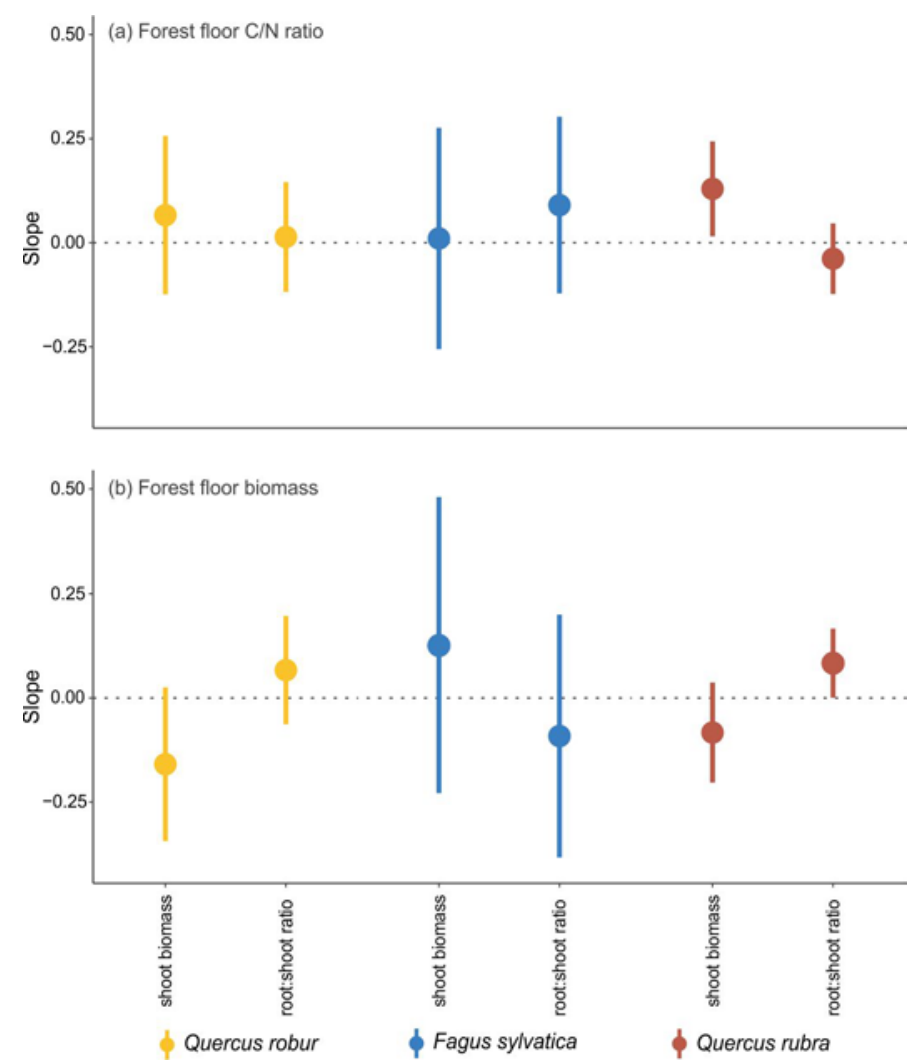

Figure B3. The relationship between the effect of FOREST FLOOR on seedling shoot biomass and root:shoot ratio on the one hand, and the $\mathrm{C} / \mathrm{N}$ ratio (a) and biomass (b) of the forest floor on the other hand. For each of the three species, the estimated slopes for the relationship between the effect sizes of the FOREST FLOOR and the different forest floor properties are shown with their $95 \%$ confidence interval. The dotted line indicates a slope of zero, i.e., no relationship between effect sizes and forest floor properties.

\section{References}

1. Brang, P.; Spathelf, P.; Larsen, J.B.; Bauhus, J.; Bončína, A.; Chauvin, C.; Drössler, L.; García-Güemes, C.; Heiri, C.; Kerr, G.; et al. Suitability of close-to-nature silviculture for adapting temperate European forests to climate change. Forestry 2014, 87, 492-503. [CrossRef]

2. Olesen, C.R.; Madsen, P. The impact of roe deer (Capreolus capreolus), seedbed, light and seed fall on natural beech (Fagus sylvatica) regeneration. For. Ecol. Manag. 2008, 255, 3962-3972. [CrossRef]

3. Watt, A.S. On the causes of failure of natural regeneration in British oakwoods. J. Ecol. 1919, 7, $173-203$. [CrossRef]

4. Crow, T.R. Reproductive mode and mechanisms for self-replacement of northern red oak (Quercus rubra) - A review. For. Sci. 1988, 34, 19-40.

5. Dey, D.C.; Gardiner, E.S.; Schweitzer, C.J.; Kabrick, J.M.; Jacobs, D.F. Underplanting to sustain future stocking of oak (Quercus) in temperate deciduous forests. New For. 2012, 43, 955-978. [CrossRef]

6. Mendoza, I.; Gómez-Aparicio, L.; Zamora, R.; Matías, L. Recruitment limitation of forest communities in a degraded Mediterranean landscape. J. Veg. Sci. 2009, 20, 367-376. [CrossRef]

7. Berkowitz, A.R.; Canham, C.D.; Kelly, V.R. Competition vs. facilitation of tree seedling growth and survival in early successional communities. Ecology 1995, 76, 1156-1168. [CrossRef]

8. Finzi, A.C.; Canham, C.D. Sapling growth in response to light and nitrogen availability in a southern New England forest. For. Ecol. Manag. 2000, 131, 153-165. [CrossRef]

9. Danner, B.T.; Knapp, A.K. Carbon and water relations of juvenile Quercus species in tall-grass prairie. J. Veg. Sci. 2001, 12, 807-816. [CrossRef] 
10. Aussenac, G. Interactions between forest stands and microclimate: Ecophysiological aspects and consequences for silviculture. Ann. For. Sci. 2000, 57, 287-301. [CrossRef]

11. Ammer, C. Growth and biomass partitioning of Fagus sylvatica L. and Quercus robur L. seedlings in response to shading and small changes in the R/FR-ratio of radiation. Ann. For. Sci. 2003, 60, 163-171. [CrossRef]

12. Anderson, L.J.; Brumbaugh, M.S.; Jackson, R.B. Water and tree-understory interactions: A natural experiment in a savanna with oak wilt. Ecology 2001, 82, 33-49.

13. Platt, K.H.; Allen, R.B.; Coomes, D.A.; Wiser, S.K. Mountain beech seedling responses to removal of below-ground competition and fertiliser addition. N. Z. J. Ecol. 2004, 28, 289-293.

14. Barberis, I.M.; Tanner, E.V.J. Gaps and root trenching increase tree seedling growth in Panamanian semi-evergreen forest. Ecology 2005, 86, 667-674. [CrossRef]

15. Packer, A.; Clay, K. Soil pathogens and spatial patterns of seedling mortality in a temperate tree. Nature 2000, 404, 278-281. [CrossRef] [PubMed]

16. Packer, A.; Clay, K. Soil pathogens and Prunus serotina seedling and sapling growth near conspecific trees. Ecology 2003, 84, 108-119. [CrossRef]

17. Binkley, D.; Giardina, C. Why do tree species affect soils? The warp and woof of tree-soil interactions. Biogeochemistry 1998, 42, 89-106. [CrossRef]

18. Finzi, A.C.; Canham, C.D.; Van Breemen, N. Canopy tree soil interactions within temperate forests: Species effects on pH and cations. Ecol. Appl. 1998, 8, 447-454. [CrossRef]

19. Reich, P.B.; Oleksyn, J.; Modrzynski, J.; Mrozinski, P.; Hobbie, S.E.; Eissenstat, D.M.; Chorover, J.; Chadwick, O.A.; Hale, C.M.; Tjoelker, M.G. Linking litter calcium, earthworms and soil properties: A common garden test with 14 tree species. Ecol. Lett. 2005, 8, 811-818. [CrossRef]

20. Winget, C.H.; Kozlowski, T.T. Yellow birch germination and seedling growth. For. Sci. 1965, 11, 386-392.

21. Facelli, J.M.; Pickett, S.T.A. Plant litter: Its dynamics and effects on plant community structure. Bot. Rev. 1991, 57, 1-32. [CrossRef]

22. Schupp, E.W. Seed-seedling conflicts, habitat choice, and patterns of plant recruitment. Am. J. Bot. 1995, 82, 399-409. [CrossRef]

23. Augusto, L.; Ranger, J.; Binkley, D.; Rothe, A. Impact of several common tree species of European temperate forests on soil fertility. Ann. For. Sci. 2002, 59, 233-253. [CrossRef]

24. Kobe, R.K.; Pacala, S.W.; Silander, J.A., Jr.; Canham, C.D. Juvenile tree survivorship as a component of shade tolerance. Ecol. Appl. 1995, 5, 517-532. [CrossRef]

25. Walters, M.B.; Reich, P.B. Are shade tolerance, survival and growth linked? Low light and nitrogen effects on hardwood seedlings. Ecology 1996, 77, 841-853. [CrossRef]

26. Flinn, K.M.; Vellend, M. Recovery of forest plant communities in post agricultural landscapes. Front. Ecol. Environ. 2005, 3, 243-250. [CrossRef]

27. De Groote, S.R.E.; van Schrojenstein Lantman, I.M.; Sercu, B.K.; Dekeukeleire, D.; Boonyarittichaikij, R.; Smith, H.K.; De Beelde, R.; Ceunen, K.; Vantieghem, P.; Matheve, H.; et al. Tree species identity outweighs the effects of tree species diversity and forest fragmentation on understorey diversity and composition. Plant Ecol. Evol. 2017, 150, 229-239. [CrossRef]

28. Brändle, M.; Brandl, R. Species richness of insects and mites on trees: Expanding Southwood. J. Anim. Ecol. 2001, 70, 491-504. [CrossRef]

29. Vansteenkiste, D.; De Boever, L.; Van Acker, J. Alternative processing solutions for red oak (Quercus rubra) from converted forests in Flanders, Belgium. In Proceedings of the Cost Action E44 Conference in Vienna on Broad-Spectrum Utilisation of Wood, Vienna, Austria, 14-15 June 2005.

30. Waterinckx, M.; Roelandt, B. De Bosinventaris Van Het Vlaamse Gewest. [The Flemish Forest Inventory] (In Dutch); Ministerie van de Vlaamse Gemeenschap, afdeling Bos \& Groen: Brussels, Belgium, 2001.

31. Baeten, L.; Verheyen, K.; Wirth, C.; Bruelheide, H.; Bussotti, F.; Finér, L.; Jaroszewicz, B.; Selvi, F.; Valladares, F.; Allan, E.; et al. A novel comparative research platform designed to determine the functional significance of tree species diversity in European forests. Perspect. Plant Ecol. Evol. Syst. 2013, 15, 281-291. [CrossRef]

32. De Groote, S.R.E.; Vanhellemont, M.; Baeten, L.; De Schrijver, A.; Martel, A.; Bonte, D.; Lens, L.; Verheyen, K. Tree species identity indirectly affects nutrient cycling through the shrub layer and its high-quality litter. Plant Soil 2017, Submitted.

33. Jabiol, B.; Brêthes, A.; Ponge, J.; Toutain, F.; Brun, J. L'humus Sous Toutes Ses Formes; École Nationale du Génie Rural des Eaux et des Forêts: Nancy, France, 1995. 
34. Buckley, R.C. Seed size and seedling establishment in tropical arid dunecrest plants. Biotropica 1982, 14, 314-315. [CrossRef]

35. Jones, R.H.; Sharitz, R.R.; Dixon, P.M.; Segal, D.S.; Schneider, R.L. Woody plant regeneration in four flood plain forests. Ecol. Monogr. 1994, 64, 345-367. [CrossRef]

36. Welander, N.T.; Ottosson, B. The influence of shading on growth and morphology in seedlings of Quercus robur L. and Fagus sylvatica L. For. Ecol. Manag. 1998, 107, 117-126. [CrossRef]

37. Sevillano, I.; Short, I.; Grant, J.; O’Reilly, C. Effects of light availability on morphology, growth and biomass allocation of Fagus sylvatica and Quercus robur seedlings. For. Ecol. Manag. 2016, 374, 11-19. [CrossRef]

38. Brookes, P.C.; Wigston, D.L.; Bourne, W.F. The dependence of Quercus robur and Q. petraea seeding on cotyledon potassium, magnesium, calcium and phosphorus during the first year of growth. Forestry 1980, 53, 167-177. [CrossRef]

39. Ellenberg, H. Vegetation Ecology of Central Europe; Cambridge University: Cambridge, UK, 2009.

40. Niinemets, Ü.; Valladares, F. Tolerance to shade, drought, and waterlogging of temperate northern hemisphere trees and shrubs. Ecol. Monogr. 2006, 76, 521-547. [CrossRef]

41. Rebbeck, J.; Gottschalk, K.; Scherzer, A. Do chestnut, northern red, and white oak germinant seedlings respond similarly to light treatments? Growth and biomass. Can. J. For. Res. 2011, 41, 2219-2230. [CrossRef]

42. Gemmel, P.; Nilsson, U.; Welander, T. Development of oak and beech seedlings planted under varying shelterwood densities and with different site preparation methods in southern Sweden. New For. 1996, 12, 141-161.

43. Davis, M.A.; Wrage, K.J.; Reich, P.B.; Tjoelker, M.G.; Schaeffer, T.; Muermann, C. Survival, growth, and photosynthesis of tree seedlings competing with herbaceous vegetation along a water-light-nitrogen gradient. Plant Biol. 1999, 145, 341-350.

44. Madsen, P. Effects of soil water content, fertilization, light, weed competition and seedbed type on natural regeneration of beech (Fagus sylvatica). For. Ecol. Manag. 1995, 72, 251-264. [CrossRef]

45. Paul, E.A. Soil Microbiology, Ecology, and Biochemistry, 3rd ed.; Academic Press: Burlington, MA, USA, 2007.

46. Brady, N.C.; Weil, R.R. The nature and Properties of Soils, 14th ed.; Pearson: Upper Saddle River, NJ, USA, 2008.

47. Bassett, I.E.; Simcock, R.C.; Mitchell, N.D. Consequences of soil compaction for seedling establishment: Implications for natural regeneration and restoration. Austral Ecol. 2005, 30, 827-833. [CrossRef]

48. Schelfhout, S.; Mertens, J.; Verheyen, K.; Vesterdal, L.; Baeten, L.; Muys, B.; De Schrijver, A. Tree species identity shapes earthworm communities. Forests 2017, 8, 85. [CrossRef]

49. Simcock, R.C.; Parfitt, R.L.; Skinner, M.F.; Dando, J.; Graham, J.D. The effects of soil compaction and fertilizer application on the establishment and growth of Pinus radiata. Can. J. For. Res. 2006, 36, 1077-1086. [CrossRef]

50. Löf, M.; Birkedal, M. Direct seeding of Quercus robur L. for reforestation: The influence of mechanical site preparation and sowing date on early growth of seedlings. For. Ecol. Manag. 2009, 258, 704-711. [CrossRef]

51. Berg, B.; McClaugherty, C. Plant Litter: Decomposition, Humus Formation, Carbon Sequestration; Springer: Berlin, Germany, 2003.

52. Brearley, F.Q.; Press, M.C.; Scholes, J.D. Nutrients obtained from leaf litter can improve the growth of dipterocarp seedlings. New Phytol. 2003, 160, 101-110. [CrossRef]

53. Facelli, J.M.; Williams, R.; Fricker, S.; Ladd, B. Establishment and growth of seedlings of Eucalyptus obliqua: Interactive effects of litter, water, and pathogens. Austral Ecol. 1999, 24, 484-494. [CrossRef]

54. Sayer, E.J. Using experimental manipulation to assess the roles of leaf litter in the functioning of forest ecosystems. Biol. Rev. 2005, 80, 1-31. [CrossRef] [PubMed]

55. Bonanomi, G.; Sicurezza, M.G.; Caporaso, S.; Esposito, A.; Mazzoleni, S. Phytotoxicity dynamics of decaying plant materials. New Phytol. 2006, 169, 571-578. [CrossRef] [PubMed]

56. Hermann, R.K.; Chilcote, W.W. Effect of Seedbeds on Germination and Survival of Douglas-Fir; Forest Management Research, Forest Research Laboratory, Oregon State University: Corvallis, OR, USA, 1965.

57. Major, K.C.; Nosko, P.; Kuehne, C.; Campbell, D.; Bauhus, J. Regeneration dynamics of non-native northern red oak (Quercus rubra L.) populations as influenced by environmental factors: A case study in managed hardwood forests of southwestern Germany. For. Ecol. Manag. 2013, 291, 144-153. [CrossRef]

58. Sayer, E.J.; Tanner, E.V.J.; Cheesman, A.W. Increased litterfall changes fine root distribution in a moist tropical forest. Plant Soil 2006, 281, 5-13. [CrossRef]

59. Tian, X.; Takeda, H.; Ando, T. Application of a rapid thin section method for observation on decomposing litter in mor humus form in a subalpine coniferous forest. Ecol. Res. 1997, 12, 289-300. [CrossRef] 
60. Fujimaki, R.; McGonigle, T.P.; Takeda, H. Soil micro-habitat effects on fine roots of Chamaecyparis obtusa Endl.: A field experiment using root ingrowth cores. Plant Soil 2005, 266, 325-332. [CrossRef]

61. Berg, B. Dynamics of nitrogen $(15 \mathrm{~N})$ in decomposing Scots pine (Pinus sylvestris) needle litter. Long-term decomposition in a Scots pine forest. VI. Can. J. Bot. 1988, 66, 1539-1546. [CrossRef]

(C) 2018 by the authors. Licensee MDPI, Basel, Switzerland. This article is an open access article distributed under the terms and conditions of the Creative Commons Attribution (CC BY) license (http://creativecommons.org/licenses/by/4.0/). 